\title{
Pathogenesis of Inflammatory Bowel Diseases
}

\author{
Masakazu Nagahori, M.D., Yasuhiro Nemoto, M.D., Ph.D., \\ Mamoru Watanabe, M.D., Ph.D. \\ Department of Gastroenterology and Hepatology, Graduate School, Tokyo Medical and Dental University, Tokyo, Japan
}

Our understanding of IBD pathogenesis has been increasing rapidly. The genetically determined interplay between the commensal microbiota, intestinal epithelial cells, and the immune system has been appreciated deeply. The interplay is also considered to be modified by specific environmental factors. This review examines the recent findings from the animal and human studies on IBD pathogenesis and the implications for future effective therapies. (Intest Res 2010;8:9-17)

Key Words: Pathogenesis; Inflammatory Bowel Diseases

\section{INTRODUCTION}

Inflammatory bowel diseases (IBD), notably ulcerative colitis (UC) and Crohn's disease (CD) are clinically distinct entities that have different characteristics and affect the colon, and any part of the gastrointestinal tract, respectively. The discordance of IBD among monozygotic twins ${ }^{1}$ along with increased incidence of IBD in immigrants to high-prevalence countries, ${ }^{2}$ shows that environmental factors should play an important role in their development. From an Asian perspective, several epidemiological studies suggest the increased incidence and prevalence of IBD, which also imply the importance of environmental factors in IBD pathogenesis. ${ }^{3-8}$ Enormous success of tumor necrotic factor (TNF)- $\alpha$ blockade in IBD treatment in 1990s opened a new era of investigation for IBD pathogenesis. Genetically determined interactions between the human intestinal microbiota and mucosal immune system and how environmental factors modify the relationships are particularly relevant in IBD development. The aim of this review is to integrate recent findings in the genetics, microbiology, and immunology of IBD and emphasize

Received April 22, 2010. Accepted June 2, 2010.

- Correspondence to : Mamoru Watanabe, M.D., Ph.D., Department of Gastroenterology and Hepatology, Tokyo Medical and Dental University, 1-5-45 Yushima, Bunkyo-ku, Tokyo 113-8519, Japan

Tel: +81-3-5803-5973, Fax: +81-3-5803-0262

E-mail: mamoru.gast@tmd.ac.jp the dynamic interplay between these components to understand the entire IBD pathogenesis.

\section{GENETICS}

Genetic studies, including candidate gene approaches, linkage mapping studies, and particularly genome-wide association studies (GWASs), have significantly advanced our understanding on the importance of genetic susceptibility in IBD. ${ }^{9}$ NOD2 gene is the most studied and well-known gene mutation with an increased susceptibility to the development of Crohn's disease. The NOD2 gene is located on chromosome 16q12 and its intracellular protein activates NF- $\kappa \mathrm{B}$ and mitogenactivated protein (MAP) kinase pathways in response to stimulation by peptidoglycan fragment muramyldipeptide in the cell walls of both Gram-positive and Gram-negative bacteria. ${ }^{10}$ Faulty in NOD2 function is considered to lead to an altered innate immune response to bacteria and resultant uncontrolled inflammation. ${ }^{11}$ Three variants (Arg702Trp, Gly908Arg, Leu1007fsinsC) are associated with increased risk of ileal and ileocolonic, but not colonic $\mathrm{CD} .{ }^{12-14}$ Interestingly enough, these mutations are associated with unique disease phenotypes, such as younger age of onset and fibro-stenotic $\mathrm{CD} .^{15,16}$

IL23R is involved in the IL12/23 pathways of inflammation. The glutamine allele of Arg $381 \mathrm{Gln}$ is much less common than the arginine allele, and appears to protect 
against development of $\mathrm{CD}$ in both non-Jewish [odds ratio $(\mathrm{OR})=0.26,95 \%$ confidence interval $(\mathrm{CI})(0.15$ to $0.43)$ ] and Jewish [OR $=0.45,95 \%$ CI ( 0.27 to 0.73$)$ ] case-control cohorts. ${ }^{17}$ IL23R gene on chromosome $1 \mathrm{p} 31$ encodes a subunit of the receptor for the proinflammatory cytokine interleukin-23. Consequently, blockade of the IL-23 signaling pathway would be a rational therapeutic target for IBD.

ATG16L mutation ${ }^{18}$ is associated with a process called autophagy, where cellular 'debris' are degraded by lysosomes, and can be used as an innate immune response to clear intracellular pathogens. ${ }^{19}$ Cadwell et al. reported that compared to ileal samples from $C D$ patients that had no risk alleles, ileal specimens from CD patients homozygous for the ATG16L1 risk allele demonstrated Paneth cell abnormalities. ${ }^{20}$ A SNP (Ala281Thr) was found to be highly associated with $\mathrm{CD}$, with the less common threonine allele being protective. ${ }^{21}$ Failed stimulation of autophagy is likely to be associated with impaired response of the innate immunity to intestinal microbial flora.

Interestingly enough, IBD risk loci are significantly different among different ethnic populations. No association was found between NOD2 variants and CD among Asian populations. ${ }^{22,23}$ GWA study, which was conducted in Japanese IBD patients and controls, identified significant association between SNPs and haplotypes within TNFSF15, which is an enhancer of interferon (IFN)- $\gamma$ production in T-cells and natural killer cells. Less significant association was also found in the study of Caucasian IBD families. Recently, three new susceptibility loci: the immunoglobulin receptor gene FCGR2A (rs1801274, $\mathrm{P}=1.56 \times 10(-12)$ ), a locus on chromosome 13q12 (rs17085007, $\mathrm{P}=6.64 \times 10(-8)$ ) and the glycoprotein gene SLC26A3 (rs2108225, $\mathrm{P}=9.50 \times$ $10(-8)$ ) were identified in a two-stage GWA study, followed by a replication study including 1384 Japanese UC patients and 3,057 controls. ${ }^{24}$ Particularly, FCGR2A was reported to be associated with other autoimmune diseases, suggesting the relevance of immune complex pathway in UC pathogenesis. ${ }^{25}$

\section{DYSBIOSIS}

It has become quite clear from genetic studies that genetics alone is insufficient to explain the development of IBD. Monozygotic twin studies show the concordance rate for disease being $40-60 \% .{ }^{1,26-28}$ It is well accepted that the environment, particularly gut flora, must play a key role in the development of disease.

A broken balance in the proportions of "protective" and "harmful" bacteria has been termed "dysbiosis", which is now considered to be vital in the pathogenesis of IBD. ${ }^{29-31}$ Higher concentrations of mucosal bacteria were found in IBD patients than in normal controls and the concentrations increased progressively with the severity of disease, both in inflamed and non-inflamed colon. ${ }^{32}$ It also has long been recognized that bacteria are essential to the development of IBD. ${ }^{33,34}$ Patients with IBD are empirically known to respond favorably to antibiotic treatment and faecal diversion and have higher antibody titers against indigenous bacteria than unaffected individuals. ${ }^{35-37}$ Furthermore, inflammation is particularly pronounced in the intestine where higher number of bacteria is present such as in terminal ileum and colon. A recent meta-genomic study compared the microbiota of patients with IBD with that of non-IBD controls by a culture-independent rRNA sequence analysis and revealed a statistically significant difference in their composition. ${ }^{38}$ Specifically, the microbiota of IBD patients showed abnormal microbial composition that was characterized by depletion of two phyla of bacteria, the Firmicutes and Bacteriodetes, which are both prominently represented in non-IBD controls. However, it is unknown whether these altered microbiota in IBD patients is the primary pathogenesis of IBD or just the secondary outcome of the inflammation.

The term probiotics is used to describe dietary microorganisms that are beneficial to the health of the host. ${ }^{39}$ Recent evidence also suggests that the induction of Treg cells by these microorganisms is essential in their ability to suppress inflammation and disease. Treatment of colitis mice with the probiotic cocktail VSL\#3 increased the production of IL-10 and the proportion of TGF $\beta$-expressing T cells. ${ }^{40}$ Furthermore, transfer of lamina propria mononuclear cells from VSL\#3-treated mice prevented colitis in recipient mice. The suggested probiotic mechanisms include not only immunomodulation, which was described above, but also competitive exclusion of microbial pathogens, 
antimicrobial activity, and enhanced barrier activity, and T-cell apoptosis. ${ }^{41}$

Intestinal mucosal immune system consists of orchestra of various innate and acquired immune mechanisms, which will be discussed below and summarized in Fig. 1.

\section{INTESTINAL EPITHELIUM}

Intestinal epithelium is a physical barrier that prevents excessive bacteria and other antigens from entering into the circulation. Normal barrier function is dependent

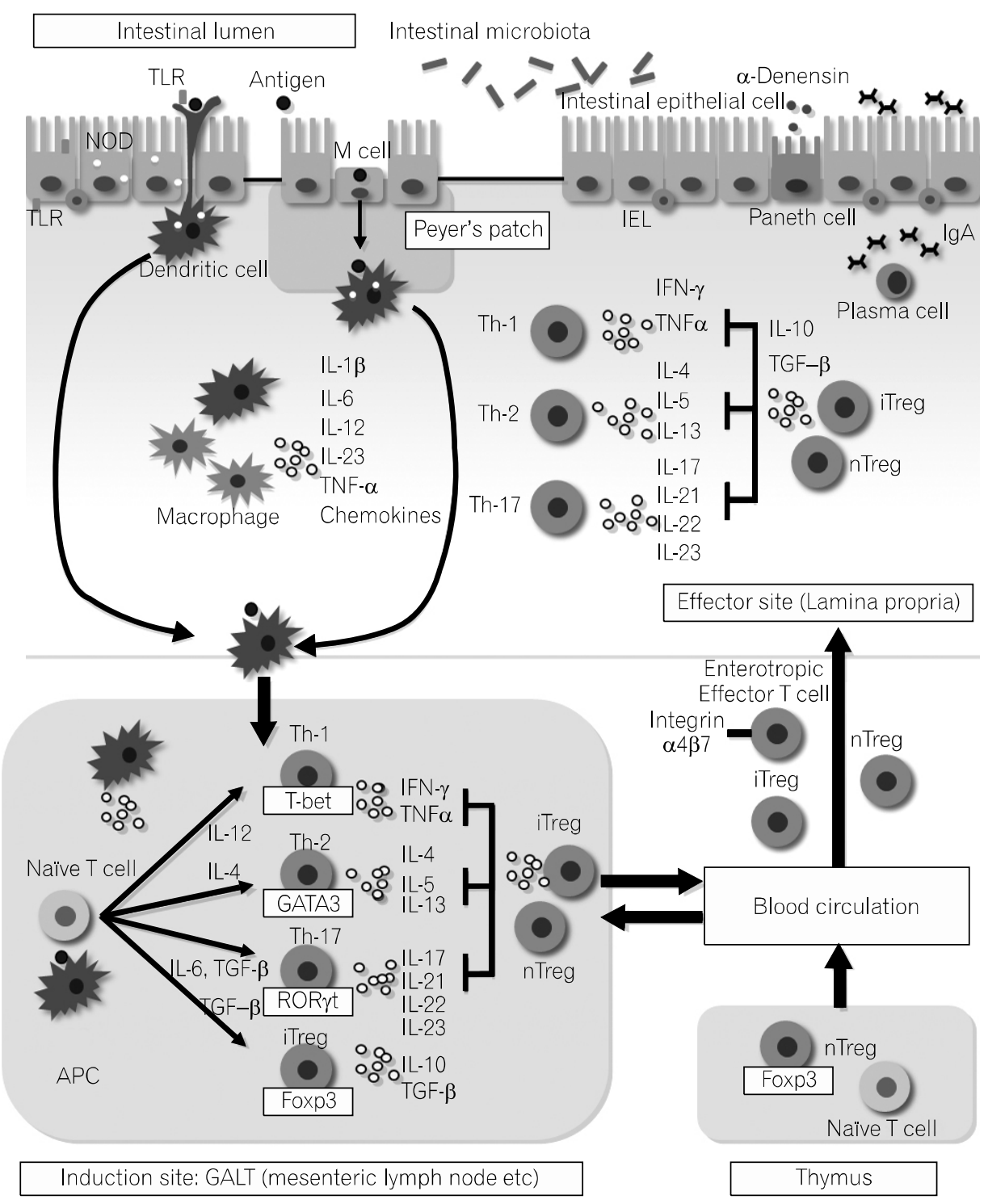

Fig. 1. Intestinal mucosal immune system. Intestinal mucosal immune system consists of orchestra of various innate and acquired immune mechanisms. Innate immune mechanism includes barrier function of intestinal epithelial cells, secretion of antimicrobial peptide such as $\alpha$-defensins from paneth cells, innate microbial sensing by epithelial cells and dendritic cells through TLRs or NOD, and activation of macrophage and dendritic cells, which leads to phagocytosis or proinflammatory cytokine production. Acquired immune mechanism includes activation of Th1, Th2 or Th17 effector T cells, which leads to production of effector cytokines, cellular immunity of killer T cells, and secretion of IgA by plasma cells. Regulatory T cells suppress effector T cells in the lymphoid organ and lamina propria, which contribute to the homeostasis of intestinal immune system. 
upon the intercellular junctions. But in IBD patients, the paracellular space has increased permeability and the regulation of tight junction is disruptive. ${ }^{42}$ Another barrier mechanism consists of specialized cells such as goblet cells and Paneth cells. Goblet cells play an important role for regulating the production of mucus, as well as for repairing epithelium and regulating inflammation. Paneth cells secrete antimicrobial peptides such as $\alpha$-defensins into the small intestinal lumen. In ileal Crohn's disease patients, $\alpha$-defensins in Paneth cells are deficient, which result in increased exposure to intestinal microbiota and subsequent inflammation. ${ }^{43,44}$ Other possible disorders of epithelial functions were derived from the results of genome-wide association maps. For example, polymorphisms close to the gene encoding EP4 (PTGER4) were implicated in Crohn's disease. ${ }^{45}$ Moreover, a variant in a genomic region that includes the gene encoding MUC19, one of gel-forming mucins, has been associated with Crohn's disease.

Endoplasmic reticulum (ER)-mediated stress responses in intestinal epithelial cells are enhanced in IL-10 deficient mice as wall as in IBD patients, thus may contribute to the chronic intestinal inflammation. ${ }^{46}$ The transcription factor XBP1 is a key component of the endoplasmic reticulum (ER) stress response, which is a cellular response triggered by various environmental changes. An association of XBP1 variants and both UC and Crohn's disease was identified. ${ }^{47}$

IL-22 is known to contribute to increased epithelial resistance to injury by microbial infection in gut. ${ }^{48}$ Recently, a population of $\mathrm{NKp} 46^{+}$cells that expressed $\operatorname{ROR} \gamma \mathrm{t}$, which is a transcription factor previously associated with lymphoid tissue-inducer cell, were found. ${ }^{49}$ They also produced interleukin-22, a member of IL-10 family of cytokines, suggesting their role as detectors of epithelial cell damage.

Notch signaling regulates differentiation and proliferation of intestinal epithelial cells. ${ }^{50}$ In ulcerative colitis patients, Notch signaling is activated in increased number of epithelial cells, resulting in goblet cell depletion and ectopic expression of PLA2G2A. Also, inhibitor of Notch signaling significantly exacerbated a mice model of colitis, by suppressing the regenerative response of the epithelium. ${ }^{51}$ Thus, Notch signaling may function as a key molecular pathway in epithelial regeneration of IBD patients.

\section{INNATE IMMUNITY}

Innate immunity is the ancient form of immunity that is not specific for pathogens. It is responsible for the initial and rapid immune responses, which localize and eradicate invading pathogens for the host's survival. ${ }^{52}$ In the intestine, innate immunity includes the epithelial barrier and phagocytic cells within the lamina propria (macrophages, dendritic cells [DCs], and neutrophils). They express various types of innate immune receptors such as toll-like receptor (TLR) and Nod-like receptor (NLR), which recognize general microbial patterns, in contrast to antigen specific receptors such as $\mathrm{T}$ cell receptors or immunoglobulins of the adoptive immune system. These receptors not only mediate defense against luminal microbiota but also regulate tolerance of epithelial and antigen presenting cells. ${ }^{53}$ The down-regulation of the expression and response of these receptors limit activation of intestinal epithelial cells by luminal microbes, which contribute to homeostasis of intestine. ${ }^{54}$ Sampling of intestinal microbiota is also important for the regulation of intestinal immune system. Microbial sampling occurs by translocation of microbes across epithelial cells or M cells in Peyer's patches, by immunoglobulin or dendritic cells. ${ }^{55}$ Activated antigen presenting cells then present peptide antigen to $\mathrm{T}$ cells in secondary lymphoid organs, such as mesenteric lymph nodes and Peyer's patches. This encounter initiates the subsequent adaptive immune response.

NOD2 is an intracellular sensor of peptidoglycan, a component of bacterial cell walls. As mentioned above, it is reported that three polymorphism of NOD2 gene increase frequency of $\mathrm{CD}$ in European or American, but not Asian populations. ${ }^{56}$ The activation of the NOD2 protein by bacterial peptidoglycan activates NF- $\kappa \mathrm{B}$ and MAP kinase signaling pathway, which leads to the production of proinflammatory cytokines such as TNF or IL- $1 \beta .^{57}$ These NOD2 carriers show decreased secretion of proinflammatory cytokines and decreased activation of NF- $\kappa \mathrm{B}$ on stimulation of NOD2 with bacterial peptidoglycan. ${ }^{58}$ How NOD2 impairment increases susceptibility to $\mathrm{CD}$ is unknown, but it 
suggests deep association of pathogenesis of IBD with innate immune system.

Alternation of TLR3 and TLR4 expression of intestinal epithelial cells of IBD patients has been reported. ${ }^{59}$ In addition, some groups reported that polymorphism of TLR4 gene is associated with the development of UC and $\mathrm{CD}^{60}$

\section{ADAPTIVE IMMUNITY}

Despite the increased knowledge about the role of innate immunity in the intestinal inflammation, the adaptive immunity, specifically helper $\mathrm{T}$ cells (Th), has been most closely correlated with IBD pathogenesis. ${ }^{61,62}$ Adaptive immunity is characterized by specificity and memory and is mostly medicated by lymphocytes that express antigen receptors on their surface. ${ }^{63}$ When naive $\mathrm{T}$ cells are presented specific antigen by antigen-presenting cells in secondary lymphoid organ, they differentiate to effector $\mathrm{T}$ cells. Following the elimination of antigen, most of effector cells undergo apoptosis, and then a small number of memory $\mathrm{T}$ cells survive. At the second attack of antigen, memory $\mathrm{T}$ cells rapidly differentiate to effector cells and exert effector function, which is the system of immunological memory. CD4 ${ }^{+}$ effector $\mathrm{T}$ cells can be divided into three different subgroups, Th1, Th2 or Th17, which secrete characteristic types of cytokine. Th1 cells produce IFN- $\gamma$ and TNF- $\alpha$, and play an important role for the protection against intracellular microbes. Th2 cells produce IL-4, IL-5 and IL-13 and they direct the immune response against extracellular pathogens including parasites. Th1 differentiation is mainly driven by IL-12 under the control of transcription factor T-bet. On the other hand, Th2 differentiation is induced by IL- 4 under the control of GATA-3. ${ }^{64}$ In addition to these subgroups, Th17 has been identified, which are important in host defense against bacterial and fungal infections. ${ }^{65}$ These cells produce IL-17, IL-22 and IL-23. Th17 cells are induced by the combination of IL6 and transforming growth factor (TGF)- $\beta$ under the control of ROR $\gamma \mathrm{t}^{66,67} \mathrm{IL}-23$ is made of $\mathrm{p} 19$ and $\mathrm{p} 40$ subunit. The $\mathrm{p} 40$ cytokine subunit is common to both IL-12 and IL-23. IL-23 is important for the maintenance of Th17 cells.

Classically, CD has been considered as Thl type disease, which shows increased pro-inflammatory cytokines such as tumor necrotic factor (TNF) and interferon- $\gamma$ (IFN- $\gamma$ ), while UC has been considered as Th2 cell-medicated disease. ${ }^{68}$ However, the absence of IL-4 in the UC mucosa and the fact that both IL-13 and IFN- $\gamma$ are increased in the UC mucosa has us reconsider the idea. ${ }^{69}$ In UC patients, IL-13 was reported to impair epithelial barrier function by affecting epithelial apoptosis, tight junctions, and restitution velocity. ${ }^{70}$

Recently, Th17 cells has been described and implicated in the pathogenesis of human and murine colitis. $^{17,71-75}$ IL-23 or Th17 cytokines were elevated several animal models of IBD that had been thought as Th1 or Th2 type disease. IL-23p19 transgenic mice develop systemic autoimmune disease including chronic colitis. ${ }^{76}$ Some models aggravate colitis when they are administered with rIL-23. ${ }^{77}$ In addition, neutralization or genetic defect of IL-23 ameliorates colitis in some models. $^{72}$ As mentioned above, in human, several GWASs revealed highly significant associations between Th17/IL-23 pathway and IBD. ${ }^{78}$ Elevated expression of IL-17, IL-21, IL-22, IL-23, ROR $\gamma \mathrm{t}$ and IL-23R in inflamed mucosa of $\mathrm{CD}$ and $\mathrm{UC}$ patient is reported. ${ }^{79}$ Furthermore, specific subset of macrophages, which secreted IL-23, TNF and IL-6, are increased in intestinal mucosa of CD patient. ${ }^{80}$ Recently, anti-p40 monoclonal antibodies have been reported to effective for $\mathrm{CD}$, which suggest the importance of Th17/IL23 pathway in IBD. ${ }^{81}$

Regulatory $\mathrm{T}$ cells (Treg) are special subset of $\mathrm{T}$ cells, which suppress the effector function of other $\mathrm{T}$ cells, and play important roles in the homeostasis of intestinal mucosal immune system. Regulatory $\mathrm{T}$ cells consist of some different groups. Although how regulatory $\mathrm{T}$ cells suppress effector function is not fully understood, inhibitory cytokines such as IL-10 or TGF- $\beta$ is thought to play important roles. ${ }^{82} \mathrm{CD} 4{ }^{+} \mathrm{CD} 25^{+}$Treg that develops in thymus is referred to as 'natural' Treg (nTreg). These cells express the transcription factor Foxp3, which is master regulator of nTreg. Recently, it has been reported that $\mathrm{CD} 4{ }^{+} \mathrm{CD} 25^{+} \mathrm{Foxp}^{+} \mathrm{T}$ cells can be induced by TGF- $\beta$ in the absence of IL- 6 in vitro. This Treg should be referred to as 'induced' Treg (iTreg). ${ }^{67}$

Scurfy mice, which defect Foxp3 gene, develop 
severe autoimmune disease including chronic colitis. Furthermore, in several animal models, dysfunction or depletion of Treg cause excess activation of effector $\mathrm{T}$ cells against intestinal microbiota, which lead to chronic colitis. In human, patients of $\mathrm{CD}$ and $\mathrm{UC}$ have decreased number of $\mathrm{CD} 4{ }^{+} \mathrm{CD} 25^{+}$Treg cells during active disease. Although several studies showed that intestinal inflamed mucosa of $\mathrm{CD}$ and $\mathrm{UC}$ patient contain increased number of Treg compared to healthy control, colonic biopsies from IBD patient have a reduced proportion of Treg compared with those from non-IBD patient such as diverticulitis. ${ }^{83}$ Regulatory function of Treg form IBD patient was not impaired. ${ }^{84}$ These findings suggest that collapse of balance between Treg and effector $\mathrm{T}$ cells may occur in IBD, rather than their defect or dysfunction.

IL-10 is important inhibitory cytokine. IL-10 $0^{-1-}$ mice develop chronic colitis. There is a genetic association between IL10 and UC. ${ }^{85}$ In addition, it was reported that uncommon recessive loss-of-function mutation in either IL10RA or IL10RB resulted in $\mathrm{CD}{ }^{86}$

IL-2 is essential maintenance factor for $\mathrm{CD} 4{ }^{+} \mathrm{CD} 25^{+}$ Foxp ${ }^{+}$Treg. Indeed, IL- $2^{-1-}$ mice develop chronic colitis as a result of reduced number of Treg. It is reported that $\mathrm{T}$ cells in the intestinal mucosa of $\mathrm{UC}$ and CD patient produce lower amount of IL-2 than those of healthy control, which may be one of mechanisms of relative decreased proportion of Treg in colonic mucosa of IBD patient. ${ }^{87}$

IL-7 is homeostatic cytokine that is secreted by stromal cells in the bone marrow and thymus and other epithelial cells including intestinal goblet cells. IL-7 is a critical key cytokine controlling survival of peripheral resting $\mathrm{CD}^{+}{ }^{+} \mathrm{T}$ cells, including naïve and memory cells but not effector cells. We have assumed that colitogenic memory $\mathrm{T}$ cells, which survive for life long even in remission, play important roles in the perpetuation of IBD, and noticed IL-7 as the important survival factor for these cells. We have previously demonstrated that IL-7 transgenic mice developed chronic colitis that mimicked histopathological characteristics of human IBD. ${ }^{88}$ In addition, the selective elimination of $\mathrm{CD}^{+}$ IL-7R $\alpha^{\text {high }} \mathrm{T}$ cells by anti-IL-7R $\alpha \mathrm{mAb}$ or genetic depletion of IL-7 ameliorated colitis in animal model. ${ }^{89}$ These findings suggest that therapeutic approaches targeting systemic IL-7 may be epoch-making therapy for the treatment of IBD, which can "reset" the pathogenic memory.

\section{LEUKOCYTE MIGRATION AND MICROVASCULATURE}

The entry of $\mathrm{T}$ cells into intestinal tissues is regulated by adhesion molecules such as selectins and integrins, and chemokines. Activated $\mathrm{T}$ cells in the secondary lymphoid organs become gut-tropic cells by expressing the integrin $\alpha_{4} \beta_{7}$ and the chemokine receptor CCR9. ${ }^{90,91}$ In the priming of gut-homing specificity, the retinol metabolite, retinoic acid, was reported to enhance the expression of the adhesion molecules. ${ }^{92}$ Medications that stop the entry of $\mathrm{T}$ cells into the gut would be expected to have a beneficial effect on intestinal inflammation. Currently, $\alpha_{4} \beta_{7}$-based anti-integrin therapy seems to be beneficial for a subgroup of, but not all IBD patients, suggesting its simultaneous effect on the suppressor cell group.

In IBD, microvasculature contributes to chronic inflammation by altered leukocyte recruitment, impaired perfusion, and angiogenesis leading to tissue remodeling. ${ }^{93}$ Consequently, microvasculature is considered to be another therapeutic target for IBD.

\section{LIPID METABOLISM}

PPAR (peroxisome proliferator-activated receptor)- $\gamma$ is a lipid-activated transcription factor and expressed in liver, adipose tissue, IECs, and hematopoietic cells involved in the regulation of lipid metabolism, inflammation, and cancer. ${ }^{94,95}$ PPAR- $\gamma$ is prominently expressed in the intestinal epithelium, which is dependent on the intestinal microbiota, and regulated by microbial metabolites. $^{96} \mathrm{UC}$ patients show decreased expression of PPAR- $\gamma$ in IECs but not in hematopoietic cells, suggesting the impaired PPAR- $\gamma$ signaling in UC pathogenesis. ${ }^{97}$ In animal models, conditional PPAR- $\gamma$ depletion in the intestinal epithelium leads to spontaneous colitis, increased susceptibility to DSS colitis, and prevention of the beneficial effects by PPAR- $\gamma$ agonists. ${ }^{98}$ Recently, the association between PPAR- $\gamma$ signaling and ER stress is suggested. Pioglitazone was 
reported to reduce ER stress and prevent diabetes by pancreatic islet cell protection. ${ }^{99}$

\section{CONCLUSION}

Advancing understanding in the complex interactions between genetics, environmental factors such as commensal intestinal bacteria, and immunological factors in IBD is expected to allow us to identify several key points where intestinal inflammation can be modulated, and expand our treatment options for IBD.

\section{REFERENCES}

1. Halme L, Paavola-Sakki P, Turunen U, et al. Family and twin studies in inflammatory bowel disease. World J Gastroenterol 2006;12:3668-3672.

2. Tsironi E, Feakins RM, Probert CS, et al. Incidence of inflammatory bowel disease is rising and abdominal tuberculosis is falling in Bangladeshis in East London, United Kingdom. Am J Gastroenterol 2004;99:1749-1755.

3. Asakura K, Nishiwaki $\mathrm{Y}$, Inoue $\mathrm{N}$, et al. Prevalence of ulcerative colitis and Crohn's disease in Japan. J Gastroenterol 2009;44:659-665.

4. Yang SK, Hong WS, Min YI, et al. Incidence and prevalence of ulcerative colitis in the Songpa-Kangdong District, Seoul, Korea, 1986-1997. J Gastroenterol Hepatol 2000;15:1037-1042.

5. Yang SK, Yun S, Kim JH, et al. Epidemiology of inflammatory bowel disease in the Songpa-Kangdong district, Seoul, Korea, 1986-2005: a KASID study. Inflamm Bowel Dis 2008;14: 542-549.

6. Leong RW, Lau JY, Sung JJ. The epidemiology and phenotype of Crohn's disease in the Chinese population. Inflamm Bowel Dis 2004;10:646-651.

7. Lok $\mathrm{KH}$, Hung $\mathrm{HG}, \mathrm{Ng} \mathrm{CH}$, et al. The epidemiology and clinical characteristics of Crohn's disease in the Hong Kong Chinese population: experiences from a regional hospital. Hong Kong Med J 2007;13:436-441.

8. Lok $\mathrm{KH}$, Hung $\mathrm{HG}, \mathrm{Ng} \mathrm{CH}$, et al. Epidemiology and clinical characteristics of ulcerative colitis in Chinese population: experience from a single center in Hong Kong. J Gastroenterol Hepatol 2008;23:406-410.

9. Van Limbergen J, Wilson DC, Satsangi J. The genetics of Crohn's disease. Annu Rev Genomics Hum Genet 2009;10: 89-116.

10. van Heel DA, Hunt KA, King K, et al. Detection of muramyl dipeptide-sensing pathway defects in patients with Crohn's disease. Inflamm Bowel Dis 2006;12:598-605.

11. Inohara N, Ogura Y, Nuñez G. Nods: a family of cytosolic proteins that regulate the host response to pathogens. Curr Opin Microbiol 2002;5:76-80.

12. Hugot JP, Chamaillard M, Zouali H, et al. Association of NOD2 leucine-rich repeat variants with susceptibility to Crohn's disease. Nature 2001;411:599-603.
13. Ogura Y, Bonen DK, Inohara N, et al. A frameshift mutation in NOD2 associated with susceptibility to Crohn's disease. Nature 2001;411:603-606.

14. Lesage S, Zouali H, Cézard JP, et al. CARD15/NOD2 mutational analysis and genotype-phenotype correlation in 612 patients with inflammatory bowel disease. Am J Hum Genet 2002;70:845-857.

15. Weiss B, Shamir R, Bujanover Y, et al. NOD2/CARD15 mutation analysis and genotype-phenotype correlation in Jewish pediatric patients compared with adults with Crohn's disease. J Pediatr 2004;145:208-212.

16. Abreu MT, Taylor KD, Lin YC, et al. Mutations in NOD2 are associated with fibrostenosing disease in patients with Crohn's disease. Gastroenterology 2002;123:679-688.

17. Duerr RH, Taylor KD, Brant SR, et al. A genome-wide association study identifies IL23R as an inflammatory bowel disease gene. Science 2006;314:1461-1463.

18. Rioux JD, Xavier RJ, Taylor KD, et al. Genome-wide association study identifies new susceptibility loci for Crohn disease and implicates autophagy in disease pathogenesis. Nat Genet 2007;39:596-604.

19. Levine B, Deretic V. Unveiling the roles of autophagy in innate and adaptive immunity. Nat Rev Immunol 2007;7:767-777.

20. Cadwell K, Patel KK, Komatsu M, Virgin HW 4th, Stappenbeck TS. A common role for Atg16L1, Atg5 and Atg7 in small intestinal Paneth cells and Crohn disease. Autophagy 2009;5:250-252.

21. Hampe J, Franke A, Rosenstiel P, et al. A genome-wide association scan of nonsynonymous SNPs identifies a susceptibility variant for Crohn disease in ATG16L1. Nat Genet 2007; 39:207-211.

22. Leong RW, Armuzzi A, Ahmad T, et al. NOD2/CARD15 gene polymorphisms and Crohn's disease in the Chinese population. Aliment Pharmacol Ther 2003;17:1465-1470.

23. Yamazaki K, Takazoe M, Tanaka T, Kazumori T, Nakamura Y. Absence of mutation in the NOD2/CARD15 gene among 483 Japanese patients with Crohn's disease J Hum Genet 2002;47:469-472.

24. Asano K, Matsushita T, Umeno J, et al. A genome-wide association study identifies three new susceptibility loci for ulcerative colitis in the Japanese population. Nat Genet 2009; 41:1325-1329.

25. Salmon JE, Millard S, Schachter LA, et al. Fc gamma RIIA alleles are heritable risk factors for lupus nephritis in African Americans. J Clin Invest 1996;97:1348-1354.

26. Orholm M, Binder V, Sørensen TI, Rasmussen LP, Kyvik KO. Concordance of inflammatory bowel disease among Danish twins. Results of a nationwide study. Scand J Gastroenterol 2000;35:1075-1081.

27. Halfvarson J, Bodin L, Tysk C, Halfvarson J, Bodin L. Inflammatory bowel disease in a Swedish twin cohort: a long-term follow-up of concordance and clinical characteristics. Gastroenterology 2003;124:1767-1773.

28. Halfvarson J, Jess T, Bodin L, et al. Longitudinal concordance for clinical characteristics in a Swedish-Danish twin population with inflammatory bowel disease. Inflamm Bowel Dis 2007; 13:1536-1544.

29. Sartor RB. Intestinal microflora in human and experimental 
inflammatory bowel disease. Curr Opin Gastroenterol 2001;17: 324-330.

30. Farrell RJ, LaMont JT. Microbial factors in inflammatory bowel disease. Gastroenterol Clin North Am 2002;31:41-62.

31. Tamboli CP, Neut C, Desreumaux P, Colombel JF. Dysbiosis in inflammatory bowel disease. Gut 2004;53:1-4.

32. Swidsinski A, Ladhoff A, Pernthaler A, et al. Mucosal flora in inflammatory bowel disease. Gastroenterology 2002;122: 44-54.

33. Sellon RK, Tonkonogy S, Schultz M, et al. Resident enteric bacteria are necessary for development of spontaneous colitis and immune system activation in interleukin-10-deficient mice. Infect Immun 1998;66:5224-5231.

34. Taurog JD, Richardson JA, Croft JT, et al. The germfree state prevents development of gut and joint inflammatory disease in HLA-B27 transgenic rats. J Exp Med 1994;180:2359-2364.

35. Macpherson A, Khoo UY, Forgacs I, Philpott-Howard J, Bjarnason I. Mucosal antibodies in inflammatory bowel disease are directed against intestinal bacteria. Gut 1996;38:365-375.

36. Elson CO. Commensal bacteria as targets in Crohn's disease. Gastroenterology 2000;119:254-257.

37. Tannock GW. Exploring the relationships between intestinal microflora and inflammatory conditions of the human bowel and spine. Antonie Van Leeuwenhoek 2002;81:529-535.

38. Frank DN, St Amand AL, Feldman RA, Boedeker EC, Harpaz N, Pace NR. Molecular-phylogenetic characterization of microbial community imbalances in human inflammatory bowel diseases. Proc Natl Acad Sci U S A 2007;104: 13780-13785.

39. Sartor RB. Therapeutic manipulation of the enteric microflora in inflammatory bowel diseases: antibiotics, probiotics, and prebiotics. Gastroenterology 2004;126:1620-1633.

40. Di Giacinto C, Marinaro M, Sanchez M, Strober W, Boirivant M. Probiotics ameliorate recurrent Th1-mediated murine colitis by inducing IL-10 and IL-10-dependent TGF-beta-bearing regulatory cells. J Immunol 2005;174:3237-3246.

41. Fedorak RN, Madsen KL. Probiotics and the management of inflammatory bowel disease. Inflamm Bowel Dis 2004;10: 286-299.

42. Turner JR. Molecular basis of epithelial barrier regulation: from basic mechanisms to clinical application. Am J Pathol 2006; 169:1901-1909.

43. Wehkamp J, Salzman NH, Porter E, et al. Reduced paneth cell alpha-defensins in ileal Crohn's disease. Proc Natl Acad Sci U S A 2005;102:18129-18134.

44. Simms LA, Doecke JD, Walsh MD, Huang N, Fowler EV, Radford-Smith GL. Reduced alpha-defensin expression is associated with inflammation and not NOD2 mutation status in ileal Crohn's disease. Gut 2008;57:903-910.

45. Libioulle C, Louis E, Hansoul S, et al. Novel Crohn disease locus identified by genome-wide association maps to a gene desert on 5 p13.1 and modulates expression of PTGER4. PLoS Genet 2007;3:e58.

46. Shkoda A, Ruiz PA, Daniel H, et al. Interleukin-10 blocked endoplasmic reticulum stress in intestinal epithelial cells: impact on chronic inflammation. Gastroenterology 2007;132: 190-207.

47. Kaser A, Lee AH, Franke A, et al. XBP1 links ER stress to intestinal inflammation and confers genetic risk for human inflammatory bowel disease. Cell 2008;134:743-756.

48. Zheng Y, Valdez PA, Danilenko DM, et al. Interleukin-22 mediates early host defense against attaching and effacing bacterial pathogens. Nat Med 2008;14:282-289.

49. Luci C, Reynders A, Ivanov II, et al. Influence of the transcription factor RORgammat on the development of NKp46+ cell populations in gut and skin. Nat Immunol 2009;10:75-82.

50. Okamoto R, Watanabe M. Molecular and clinical basis for the regeneration of human gastrointestinal epithelia. J Gastroenterol 2004;39:1-6.

51. Okamoto R, Tsuchiya K, Nemoto Y, et al. Requirement of Notch activation during regeneration of the intestinal epithelia. Am J Physiol Gastrointest Liver Physiol 2009;296:G23-35.

52. Medzhitov R, Janeway C Jr. Innate immune recognition: mechanisms and pathways. Immunol Rev 2000;173:89-97.

53. Rakoff-Nahoum S, Paglino J, Eslami-Varzaneh F, Edberg S, Medzhitov R. Recognition of commensal microflora by toll-like receptors is required for intestinal homeostasis. Cell 2004;118: 229-241.

54. Lee J, Mo JH, Katakura K, et al. Maintenance of colonic homeostasis by distinctive apical TLR9 signalling in intestinal epithelial cells. Nat Cell Biol 2006;8:1327-1336.

55. Rescigno M, Urbano M, Valzasina B, et al. Dendritic cells express tight junction proteins and penetrate gut epithelial monolayers to sample bacteria. Nat Immunol 2001;2:361-367.

56. Cho JH, Weaver CT. The genetics of inflammatory bowel disease. Gastroenterology 2007;133:1327-1339.

57. Kobayashi KS, Chamaillard M, Ogura Y, et al. Nod2-dependent regulation of innate and adaptive immunity in the intestinal tract. Science 2005;307:731-734.

58. Abraham C, Cho JH. Functional consequences of NOD2 (CARD15) mutations. Inflamm Bowel Dis 2006;12:641-650.

59. Cario E, Podolsky DK. Differential alteration in intestinal epithelial cell expression of toll-like receptor 3 (TLR3) and TLR4 in inflammatory bowel disease. Infect Immun 2000;68:7010-7017.

60. Franchimont D, Vermeire S, El Housni H, et al. Deficient host-bacteria interactions in inflammatory bowel disease? The toll-like receptor (TLR)-4 Asp299gly polymorphism is associated with Crohn's disease and ulcerative colitis. Gut 2004;53:987-992.

61. Kugathasan S, Saubermann LJ, Smith L, et al. Mucosal T-cell immunoregulation varies in early and late inflammatory bowel disease. Gut 2007;56:1696-1705.

62. Brown SJ, Mayer L. The immune response in inflammatory bowel disease. Am J Gastroenterol 2007;102:2058-2069.

63. Janeway CA Jr, Bottomly K. Signals and signs for lymphocyte responses. Cell 1994;76:275-285.

64. Xavier RJ, Podolsky DK. Unravelling the pathogenesis of inflammatory bowel disease. Nature 2007;448:427-434.

65. Ouyang W, Kolls JK, Zheng Y. The biological functions of T helper 17 cell effector cytokines in inflammation. Immunity 2008;28:454-467.

66. Veldhoen M, Stockinger B. TGFbeta1, a "Jack of all trades": the link with pro-inflammatory IL-17-producing T cells. Trends Immunol 2006;27:358-361. 
67. Bettelli E, Carrier Y, Gao W, et al. Reciprocal developmental pathways for the generation of pathogenic effector TH17 and regulatory T cells. Nature 2006;441:235-238.

68. Zenewicz LA, Antov A, Flavell RA. CD4 T-cell differentiation and inflammatory bowel disease. Trends Mol Med 2009;15:199-207.

69. Bouma G, Strober W. The immunological and genetic basis of inflammatory bowel disease. Nat Rev Immunol 2003;3: 521-533.

70. Heller F, Florian P, Bojarski C, et al. Interleukin-13 is the key effector Th2 cytokine in ulcerative colitis that affects epithelial tight junctions, apoptosis, and cell restitution. Gastroenterology 2005;129:550-564.

71. Weaver CT, Hatton RD, Mangan PR, Harrington LE. IL-17 family cytokines and the expanding diversity of effector $\mathrm{T}$ cell lineages. Annu Rev Immunol 2007;25:821-852.

72. Kullberg MC, Jankovic D, Feng CG, et al. IL-23 plays a key role in Helicobacter hepaticus-induced T cell-dependent colitis. J Exp Med 2006;203:2485-2494.

73. Hue S, Ahern P, Buonocore S, et al. Interleukin-23 drives innate and $\mathrm{T}$ cell-mediated intestinal inflammation. J Exp Med 2006;203:2473-2483.

74. Schmechel S, Konrad A, Diegelmann J, et al. Linking genetic susceptibility to Crohn's disease with Th17 cell function: IL-22 serum levels are increased in Crohn's disease and correlate with disease activity and IL23R genotype status. Inflamm Bowel Dis 2008;14:204-212.

75. Kobayashi T, Okamoto S, Hisamatsu T, et al. IL23 differentially regulates the Th1/Th17 balance in ulcerative colitis and Crohn's disease. Gut 2008;57:1682-1689.

76. Wiekowski MT, Leach MW, Evans EW, et al. Ubiquitous transgenic expression of the IL-23 subunit p19 induces multiorgan inflammation, runting, infertility, and premature death. J Immunol 2001;166:7563-7570.

77. Yen D, Cheung J, Scheerens H, et al. IL-23 is essential for $\mathrm{T}$ cell-mediated colitis and promotes inflammation via IL-17 and IL-6. J Clin Invest 2006;116:1310-1316.

78. Abraham C, Cho J. Interleukin-23/Th17 pathways and inflammatory bowel disease. Inflamm Bowel Dis 2009;15:1090-1100.

79. Annunziato F, Cosmi L, Santarlasci V, et al. Phenotypic and functional features of human Th17 cells. J Exp Med 2007;204:1849-1861.

80. Kamada N, Hisamatsu T, Okamoto S, et al. Unique CD14 intestinal macrophages contribute to the pathogenesis of Crohn disease via IL-23/IFN-gamma axis. J Clin Invest 2008;118: 2269-2280.

81. Sandborn WJ, Feagan BG, Fedorak RN, et al. A randomized trial of Ustekinumab, a human interleukin-12/23 monoclonal antibody, in patients with moderate-to-severe Crohn's disease. Gastroenterology 2008;135:1130-1141.

82. Vignali DA, Collison LW, Workman CJ. How regulatory T cells work. Nat Rev Immunol 2008;8:523-532.

83. Maul J, Loddenkemper $\mathrm{C}$, Mundt $\mathrm{P}$, et al. Peripheral and intestinal regulatory $\mathrm{CD} 4+\mathrm{CD} 25$ (high) $\mathrm{T}$ cells in inflammatory bowel disease. Gastroenterology 2005;128:1868-1878.
84. Makita S, Kanai T, Oshima S, et al. CD4+CD25bright T cells in human intestinal lamina propria as regulatory cells. J Immunol 2004;173:3119-3130.

85. Franke A, Balschun T, Karlsen TH, et al. Sequence variants in IL10, ARPC2 and multiple other loci contribute to ulcerative colitis susceptibility. Nat Genet 2008;40:1319-1323.

86. Glocker EO, Kotlarz D, Boztug K, et al. Inflammatory bowel disease and mutations affecting the interleukin-10 receptor. $\mathrm{N}$ Engl J Med 2009;361:2033-2045.

87. Fiocchi C, Youngman KR, Yen-Lieberman B, Tubbs RR. Modulation of intestinal immune reactivity by interleukin 2 . Phenotypic and functional analysis of lymphokine-activated killer cells from human intestinal mucosa. Dig Dis Sci 1988;33:1305-1315.

88. Watanabe M, Ueno Y, Yajima T, et al. Interleukin 7 transgenic mice develop chronic colitis with decreased interleukin 7 protein accumulation in the colonic mucosa. J Exp Med 1998; 187:389-402.

89. Yamazaki M, Yajima T, Tanabe M, et al. Mucosal T cells expressing high levels of IL-7 receptor are potential targets for treatment of chronic colitis. J Immunol 2003;171:1556-1563.

90. Mora JR, Bono MR, Manjunath N, et al. Selective imprinting of gut-homing $T$ cells by Peyer's patch dendritic cells. Nature 2003;424:88-93.

91. Jaensson E, Uronen-Hansson H, Pabst O, et al. Small intestinal CD103+ dendritic cells display unique functional properties that are conserved between mice and humans. J Exp Med 2008;205:2139-2149.

92. Iwata M, Hirakiyama A, Eshima Y, Kagechika H, Kato C, Song SY. Retinoic acid imprints gut-homing specificity on $\mathrm{T}$ cells. Immunity 2004;21:527-538.

93. Hatoum OA, Heidemann J, Binion DG. The intestinal microvasculature as a therapeutic target in inflammatory bowel disease. Ann N Y Acad Sci 2006;1072:78-97.

94. Bensinger SJ, Tontonoz P. Integration of metabolism and inflammation by lipid-activated nuclear receptors. Nature 2008:454:470-477.

95. Dubuquoy L, Rousseaux C, Thuru X, et al. PPARgamma as a new therapeutic target in inflammatory bowel diseases. Gut 2006;55:1341-1349.

96. Wachtershauser A, Loitsch SM, Stein J. PPAR-gamma is selectively upregulated in Caco-2 cells by butyrate. Biochem Biophys Res Commun 2000;272:380-385.

97. Dubuquoy L, Jansson EA, Deeb S, et al. Impaired expression of peroxisome proliferator-activated receptor gamma in ulcerative colitis. Gastroenterology 2003;124:1265-1276.

98. Bassaganya-Riera J, Reynolds $\mathrm{K}$, Martino-Catt $\mathrm{S}$, et al. Activation of PPAR gamma and delta by conjugated linoleic acid mediates protection from experimental inflammatory bowel disease. Gastroenterology 2004;127:777-791.

99. Evans-Molina C, Robbins RD, Kono T, et al. Peroxisome proliferator-activated receptor gamma activation restores islet function in diabetic mice through reduction of endoplasmic reticulum stress and maintenance of euchromatin structure. Mol Cell Biol 2009;29:2053-2067. 